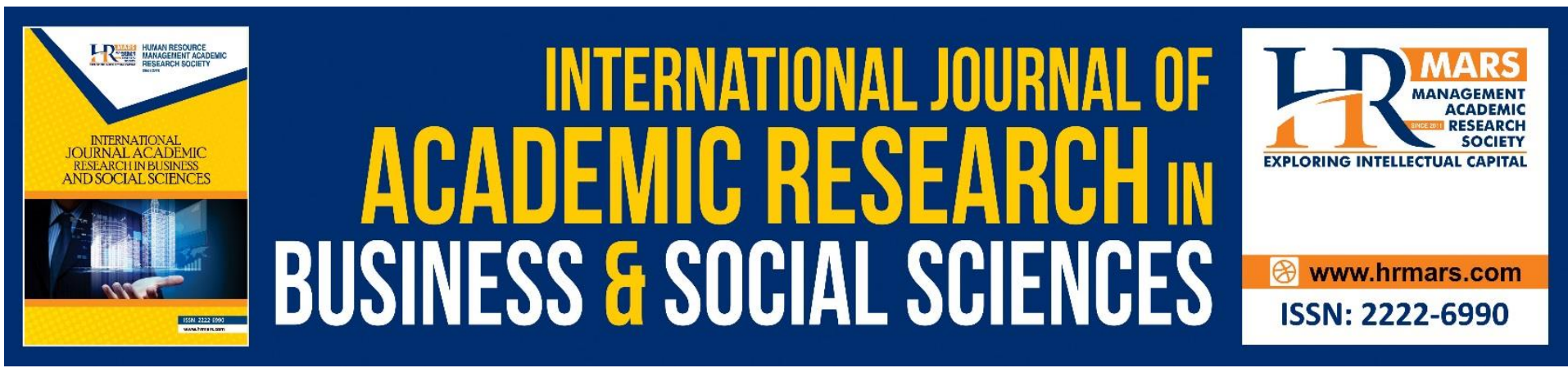

\title{
Personality Traits and Level of Motivation towards ICT Integration in the L2 Learning Context
}

Loo Kien Men, Nooreen Noordin

To Link this Article: http://dx.doi.org/10.6007/IJARBSS/v9-i1/5864

DOI: $\quad 10.6007 /$ IJARBSS/v9-i1/5864

Received: 29 Dec 2018, Revised: 17 Jan 2019, Accepted: 30 Jan 2019

Published Online: 03 Feb 2019

In-Text Citation: (Men \& Noordin, 2019)

To Cite this Article: Men, L. K., \& Noordin, N. (2019). Personality Traits and Level of Motivation towards ICT Integration in the L2 Learning Context. International Journal of Academic Research Business and Social Sciences, 9(1), 1332-1343.

Copyright: (C) 2019 The Author(s)

Published by Human Resource Management Academic Research Society (www.hrmars.com)

This article is published under the Creative Commons Attribution (CC BY 4.0) license. Anyone may reproduce, distribute, translate and create derivative works of this article (for both commercial and non-commercial purposes), subject to full attribution to the original publication and authors. The full terms of this license may be seen at: http://creativecommons.org/licences/by/4.0/legalcode

Vol. 9, No. 1, 2019, Pg. 1332- 1343

Full Terms \& Conditions of access and use can be found at http://hrmars.com/index.php/pages/detail/publication-ethics 


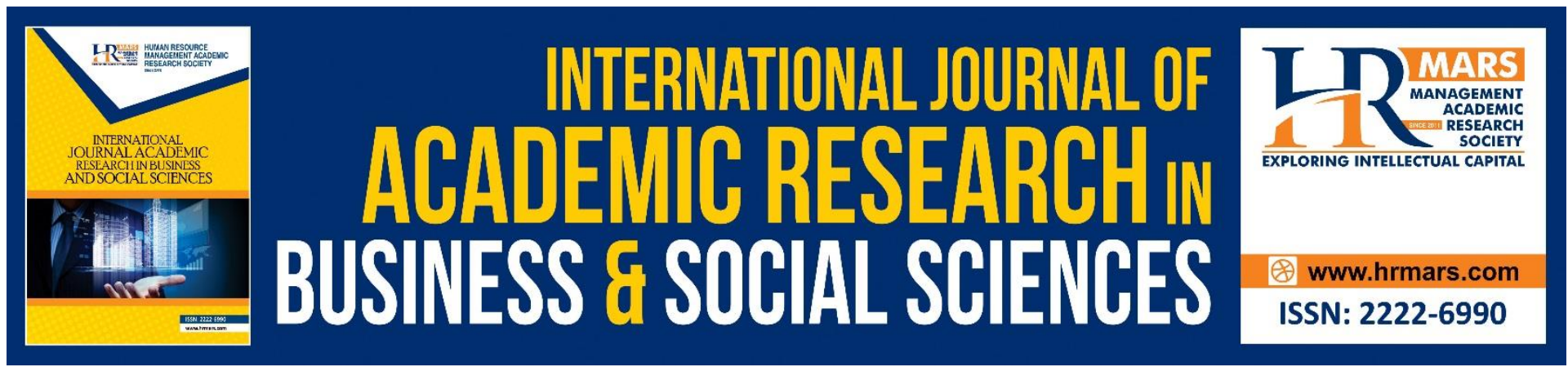

\title{
Personality Traits and Level of Motivation towards ICT Integration in the L2 Learning Context
}

\author{
Loo Kien Men \\ Eagles Grammar International School, Malaysia \\ Nooreen Noordin \\ Universiti Putra Malaysia (UPM), Malaysia
}

\begin{abstract}
Today's digital age offers the Digital Natives unmatched efficiency of learning languages and other fields of knowledge via the use of technology. Many educational policies including the Malaysia Education Blueprint (2013-2025) have taken initiatives to implement ICT in learning to cater to the various learning styles of the Digital Natives. However, findings have shown that the implementation process has not been easy as majority of teachers expressed reluctance in integrating ICT in their lessons as required. This study attempted to find out the levels of ICT integration, personality traits and motivation among undergraduates in the ESL context. Seventytwo undergraduates majoring in Teaching English as a Second Language (TESL) were involved in this quantitative study. A questionnaire and semi-structured interviews were used for data collection. Results show that their level of ICT integration in learning was high. Their level of motivation in integrating ICT in L2 learning was high as well. Next, the sample was reported to score the highest in Openness to experience, followed by Conscientiousness, Agreeableness and Extraversion towards ICT integration in L2 learning while low scores were obtained for Neuroticism. Findings also indicated that there was a significant, moderate, positive relationship between their level of motivation, Agreeableness, Conscientiousness, Extraversion and Openness traits and their ICT integration in L2 learning. These findings present vital implications for program developers at the tertiary level as well course coordinators in facilitating pre-service teachers to leverage ICT in their teaching practice.
\end{abstract}

Keywords: Big Five, Motivation, ICT, TESL undergraduates, L2 teaching and learning

\section{Introduction}

The landscape of $21^{\text {st }}$ century learning has witnessed the needs and interests of the nation changing rapidly in order to stay relevant. Owing it to the breakthroughs of social and technological advances, this 'digital revolution' and its affordances have become an integral part in the lives of today's net generation. 
Growing up with technology, they have developed a unique aptitude of impressive knowledge and skills towards information and communication technology (ICT) whereby multitasking between devices and proactively searching for information are at their fingertips have become increasingly commonplace (Lee, Thang, Tan, Ng, Yoon, Chua, \& Nadin, 2014). The implication is that a whole new learning experience is presented before them which leads to new thinking patterns, thus earning them the label "Digital Natives" (Prensky, 2001). As a result, their schemata are structured differently than the "Digital Immigrants" which significantly influences the ways the Digital Natives make connections in their learning. Hence, technology in the form of computer has slowly but surely seeped into the education scene.

Employing ICT to teach language has been proven to be effective as it appeals to the Digital Natives (Al-Mahrooqi \& Troudi, 2014). The role of teachers in employing ICT in their teaching has evolved to meet the current demands. Teachers are no longer the primary knowledge providers as their role has now become multi-faceted by facilitating their students to explore and guide their own learning process using ICT (Smeets, 2005; Rosnaini \& Mohd Arif 2010 \& Cakir, 2013). As a result, the learning environment becomes more student-centred and is able to cater more to the needs of individual differences in order to motivate and increase the student's interaction with the target language.

Despite all the hype about catering to the learning needs of Digital Natives by integrating ICT into the lessons, the level of ICT integration among teachers is still insufficient and not fully optimised (Yunus, 2007; Kim, 2008 \& Li \& Walsh, 2010). In the Malaysian context, the Preliminary Report of the Malaysia Education Blueprint 2013-2025 pointed out that, in 2010, about $80 \%$ of teachers were found to utilise ICT in their teaching for only less than an hour on a weekly basis, despite having pumped in a colossal amount of RM6 billion for ICT in education. Following this, the government's efforts in granting Internet access and virtual learning environment (VLE) to all 10,000 schools in Malaysia may go to waste if Malaysian teachers do not actively put them into good use (Lee, 2013).

There are teachers who despite witnessing the effectiveness of using ICT are still reluctant to adapt and grow with the latest, relevant teaching methods which involve the use digital technologies (Nurul Atikah, Mohd Jafre, Wong, Majid \& Hanafi, 2006). Undoubtedly, every teacher thinks, feels and behaves in a unique, consistent manner in response to the stimuli around them which makes their personality a fundamental aspect of individual differences as well having an impact in the way they teach (Pervin, \& John, 2001 \& Dörnyei, 2005). The Big Five Personality Theory posits that open individuals are the first to take initiatives to try out new technology, conscientious individuals may only use technology to a certain extend to achieve their intended goals, extraverted individuals utilise technology for social engagements and connections, agreeable individuals use technology to keep up with their friends or audience, whereas neurotic individuals may rely on technology to satisfy their personal insecurities. This shows that different personality traits impact ICT integration in the classroom differently. However, this aspect has not been fully explored particularly in the field of educational technology.

More and more studies have been conducted to examine personality traits and motivations in relation to ICT use, but their target population has always been focusing on participants who are not from the education major or the teaching profession. Students are said to be able to greatly benefit from their learning process if the teachers are able to integrate ICT seamlessly into their 
lessons (Gülbahar, 2007). However, it was also reported that pre-service teachers lack the confidence and willingness to give ICT a chance in their teaching. Hence, this study presents the opportunity to understand teacher's personality and motivation towards ICT, as different personalities will bring in different ICT experience to enhance student's learning process (Angeli \& Valanides, 2008). The present study is interested to answer the following research questions:

i. What are TESL undergraduates' levels of ICT integration in the L2 learning context?

ii. What are TESL undergraduates' levels of motivation in integrating ICT in the L2 learning context?

iii. What are the personality traits of TESL undergraduates towards ICT integration in the learning L2 context?

iv. What is the relationship between their personality traits and ICT integration in the L2 learning context?

v. What is the relationship between their level of motivation and ICT integration in the L2 learning context?

\section{Methodology}

Research Participants: The present study employed the quantitative approach comprising descriptive and correlational designs. The participants of this study were TESL undergraduates doing their degree program in UPM. There were 87 of them in total across the three cohorts undergoing the Bachelor of Education program at the Faculty of Educational Studies. Through purposive sampling, 15 participants took part in the pilot study, while the remaining 72 participated in the actual study.

Settings: Two instruments were used in the study. Firstly, the Personality and Motivation in ICT Integration Questionnaire was adapted to extract data from the participants to answer the research questions. Prior to its administration in the actual study, its validity was established by a panel of experts and its reliability confirmed by pilot study's result via Cronbach's alpha which yielded a highly acceptable value of 0.88 . Secondly, semi-structured interview sessions was also carried out which served to triangulate the findings from the questionnaire.

Procedures: The data collection was done within one week with all the three batches of TESL undergraduates, along with a semi-structured interview involving three participants from each cohort. Descriptive statistics were used to answer Research Question 1, 2 and 3 while for Research Questions 4 and 5, Pearson Correlation with the alpha level set at . 05 was used.

\section{Results}

Demographics: Majority of the participants were in their early 20s, and $75 \%$ of them were females. Although there was ethnic diversity in the sample, Malays made up $83.33 \%$ of the sample, followed by Chinese (8.33\%) and Indians (5.56\%). The distribution of participants across the three cohorts was nearly proportional with the $2^{\text {nd }}$ semester having the most number of participants $(36.11 \%)$.

\section{Level of ICT Integration among TESL Undergraduates}

According to Pallant's (2011) interpretation of mean scores, data analysis for Research Question 1 shows that the TESL undergraduates have high level of ICT integration in their L2 teaching as almost half of the items regarding ICT integration such as Internet and presentation technology scored above average mean values, while the remaining items scored within the range of moderate mean values 
(see Table 1). The three interviewees taken from the sample were well aware of the advantages of integrating ICT in their learning process, namely to engage better during the lessons, acquire information and teaching materials easier, manage work more efficiently and reduce time taken to present input in class. Meanwhile, they were also concerned with its setbacks such as glitches, distractions and its unavailability in different schools. These findings are consistent with those found in Kim's (2008), Li \& Walsh's (2010) and Uluyol \& Sahin's (2016).

Table 1. Participants' level of ICT integration in L2 teaching

\begin{tabular}{lccc}
\hline \multicolumn{1}{c}{ Item } & Mean & SD & Percentage \\
& & & $(\boldsymbol{\%})$ \\
\cline { 2 - 4 } & & & \\
& & .12 & 100 \\
Internet & 4.99 & .38 & 97.3 \\
Word processing & 4.90 & .45 & 97.2 \\
M u l t i m e d i a & 4.82 & & \\
application & & & 97.2 \\
E-mail & 4.80 & .47 & 97.3 \\
Presentation & 4.78 & .48 & 93 \\
Subj e c t - re l a te d & 4.63 & .62 & \\
program & & & 59.8 \\
Database program & 3.78 & 1.05 & 55.6 \\
Online interactive & 3.65 & .84 & 22.3 \\
content & 2.83 & .95 & \\
Drill and practice & & & 23.6 \\
Game-based learning & 2.76 & 1.12 & 19.4 \\
Graphics & 2.54 & 1.15 & 20.8 \\
Authoring & 2.38 & 1.26 & 7 \\
Spreadsheets & 2.18 & .79 & \\
\hline
\end{tabular}




\section{Level of motivation among TESL undergraduates}

Based on Table 2, results for Research Question 2 revealed that they have a high level of motivation in integrating ICT in their L2 learning as all of the 13 items regarding ICT motivation scored above average mean values. The three interviewees commented being motivated to integrate ICT to capture their students' interest, cater to their various learning styles and prepare teaching materials more efficiently. These findings are consistent with those found in Nurul Atikah's et al. (2006), Uluyol \& Sahin's (2016) and Pinner's (2012) studies on teachers' ICT motivation.

Table 2. Participants' level of motivation in ICT

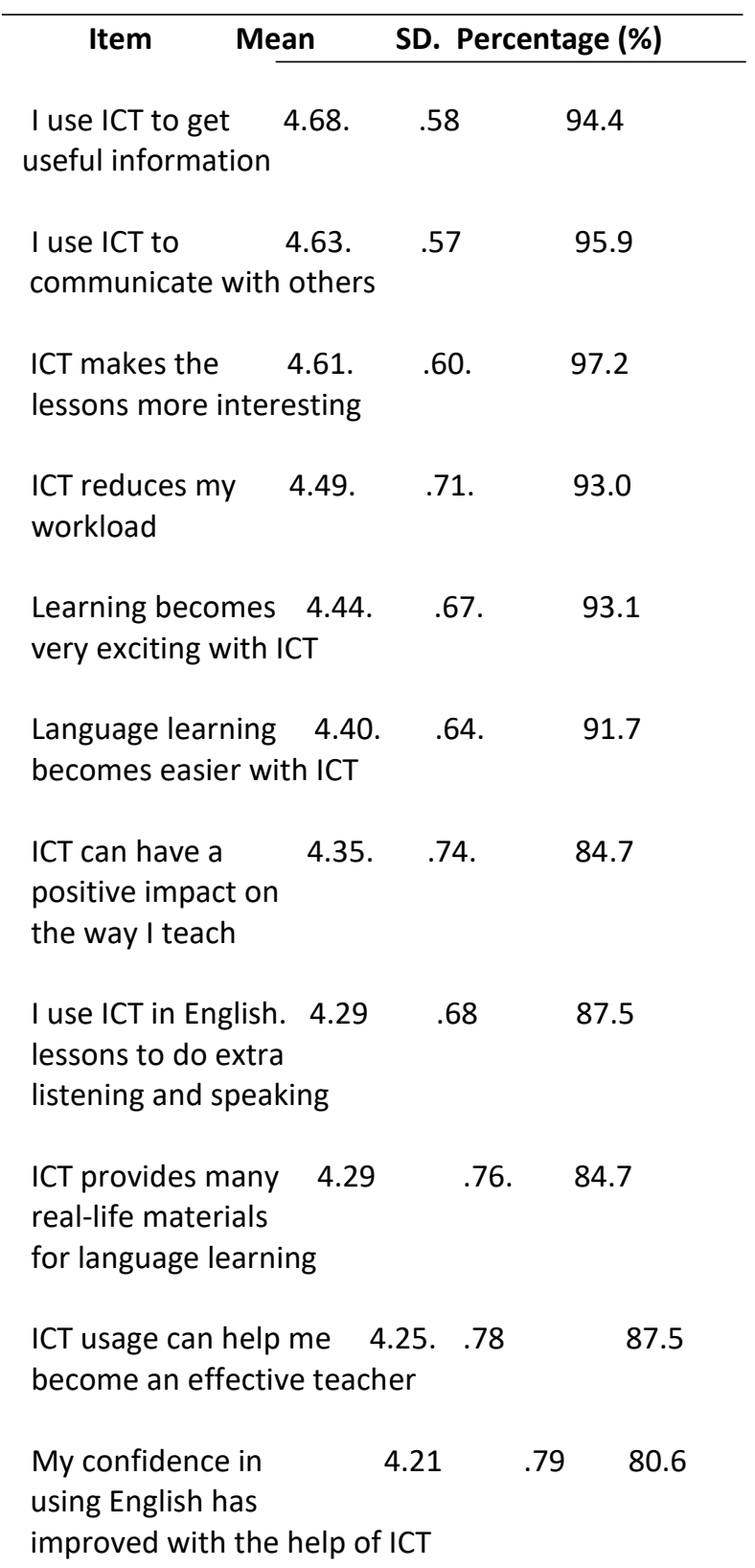

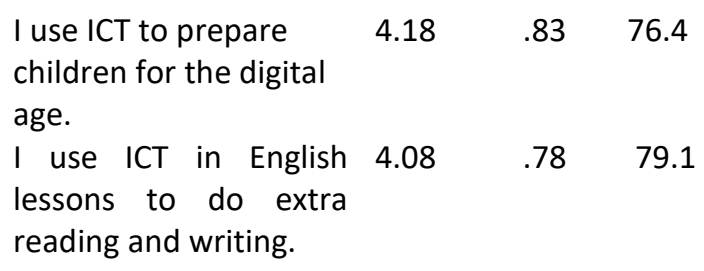




\section{Personality traits of TESL undergraduates}

Table 3 indicates the personality traits of TESL undergraduates who are predominantly open individuals towards ICT as they scored the highest for the Openness trait with the above average mean value of 4.0525. The values among the Conscientiousness, Agreeableness and Extraversion traits are very close by the decimal points and they belong to the higher end of average means.

In addition, the differences in value among these four traits are considerably small, so it can be observed that these pre-service teachers were high in Openness, Conscientiousness, Agreeableness and Extraversion. On the other hand, they scored the lowest for the Neuroticism trait with the below average mean value of 2.2875. Its value is a stark contrast to the values of other traits and it shows that the TESL undergraduates were relatively low in Neuroticism.

Table 3. Average mean values of participants' Big Five by ranking

$\begin{array}{lll}\text { No } & \text { Personality trait. } & \text { Average mean } \\ \text { 1. } & \text { Openness to experience } & 4.0525 \\ \text { 2. } & \text { Conscientiousness } & 3.8913 \\ \text { 3. } & \text { Agreeableness } & 3.8700 \\ \text { 4. } & \text { Extraversion } & 3.8650 \\ \text { 5. } & \text { Neuroticism } & 2.2875\end{array}$

During the interview with the selected interviewees, they were given a hypothetical scenario on how they would want their own students to learn in a classroom which has full access to ICT facilities and Internet connection.

Based on their responses, the way they would utilise the facilities in their teaching would reflect on their dominant Big Five as shown in the key phrases below:

"I will use everything that is provided... we cannot be old-schooled. The children now... their tendency for gadgets is higher, so make use of it."

(Sha, S2)

"I don't want my students to be distracted... I want them to focus on the things I'm gonna teach... I want them to gain information and not just having fun looking at my slides..." 
INTERNATIONAL JOURNAL OF ACADEMIC RESEARCH IN BUSINESS AND SOCIAL SCIENCES Vol. 9, No. 1, Jan, 2019, E-ISSN: 2222-6990 ㄷ 2019 HRMARS

“... I have not used the smartboard but I have seen it and it's very interesting... I do see myself producing my own teaching materials from one time to another to get the students excited without doing the same thing every single time..."

Table 4 below summarizes the interview data above which are similar with the findings of many past related studies on personality traits and behaviour towards ICT (Guadagno et al., 2008; Moore \& McElroy, 2012; Norsiah et al., 2015; Landers \& Lounsbury, 2006; McElroy et al., 2007; Wehrli, 2008; Hamburger \& Vinitzky, 2010).

Table 4. Personality traits and ICT behaviour of interviewees

\section{Interviewee Personality trait ICT behaviour}

S2

Agreeableness Cooperative (fully utilise ICT facilities) Compassionate (keep up with Digital Native students' learning styles)

S4 Conscientiousness Organised (no ICT distractions) Goal-oriented (achieve learning objectives with ICT)

\begin{tabular}{|c|c|}
\hline $\begin{array}{l}\text { Openness to } \\
\text { Experience }\end{array}$ & $\begin{array}{l}\text { Curious (smartboard } \\
\text { for class) } \\
\text { Non routine-based } \\
\text { (diversity teaching } \\
\text { materials to prevent } \\
\text { monotony) }\end{array}$ \\
\hline
\end{tabular}

\section{Relationship between personality traits and ICT integration in the L2 learning context}

The four constructs of the Big Five Personality Theory have a significant, moderate, positive relationship with ICT integration, namely Agreeableness, Conscientiousness, Extraversion and Openness to experience based on Cohen's (1988) [26] interpretation of $r$ value. These findings are similar to other previous studies (Shen et al., 2014; Ryan \& Xenos, 2011; Mark \& Ganzach, 2014) in terms of significant, positive relationship with ICT usage. Moreover, the interviewees in the present study possessed three of these four traits.

The Ministry's ICT policy for education. Their Agreeableness trait had one of the highest average mean in the top three which was 3.8700 and the S2 interviewee was an example of an agreeable individual. It was mentioned in the interview that given the opportunity, she would fully utilise all the ICT facilities in order to cater to her students' learning styles more effectively. It can be observed that she was cooperative and showing compassion in utilizing ICT for her lesson. 
On the other hand, Neuroticism is reported to have very weak, negative, not significant relationship with ICT integration. This finding is contrary to findings found in Shen et al. (2014) and Mark \& Ganzach (2014). However, the context of ICT usage that Shen et al. were focusing on was the social media only and not for academic purposes, which may have produced a different correlation outcome for Neuroticism. Although Mark \& Ganzach were focusing on ICT in the academic context, their sample was young adults in general which may not have sufficiently captured the teacher education student population because it is a niche area of focus in leveraging ICT for teaching. Hence, their correlation outcome for Neuroticism accounted for populations different from the teachers.

Table 5. Correlation between TESL undergraduates' personality traits and ICT integration

\begin{tabular}{lccc} 
Personality traits N & \multicolumn{2}{c}{$\boldsymbol{P}$} \\
Openness to experience & 72 & $.373^{* *}$ & .001 \\
Conscientiousness & 72 & $.447^{* *}$ & .000 \\
Extraversion & 72 & $.399^{* *}$ & .001 \\
Agreeableness & 72 & $.491^{* *}$ & .000 \\
Neuroticism & 72 & -.085 & .475 \\
** Correlation is significant at 0.01 level (2- \\
tailed)
\end{tabular}

\section{Relationship between TESL undergraduates' level of motivation and ICT integration}

The TESL undergraduates' level of motivation was found to be significantly related to their integration of ICT in their L2 learning (see Table 6). This finding is similar with Sang et al.'s (2011) and Perkmen \& Cevik's (2010) studies; including the qualitative results found in Uluyol \& Sahin's (2016) as well as Pinner's (2012) studies.

Table 6. Correlation between TESL undergraduates' level

\begin{tabular}{|c|c|c|}
\hline Motivation & $\mathrm{N}$ & $P$ \\
\hline Level of motivation & 72 & $.393 * * .001$ \\
\hline
\end{tabular}

** Correlation is significant at 0.01 level (2-tailed)

\section{Limitations of the Study}

Findings of the study were beneficial in determining the levels of ICT integration, personality traits and motivation among undergraduates in the ESL context. However, findings of the study cannot be generalized to be made inference upon the levels of personality traits and motivation of ESL undergraduates in Malaysian universities. This is due to the fact that the nature of this quantitative study was cross-sectional, so it was only able to capture the phenomena of TESL 
INTERNATIONAL JOURNAL OF ACADEMIC RESEARCH IN BUSINESS AND SOCIAL SCIENCES

Vol. 9, No. 1, Jan, 2019, E-ISSN: 2222-6990 ㄷ 2019 HRMARS

undergraduates' Big Five Personality Traits, level of motivation and ICT integration at one point of time. Therefore, the findings are not rich enough to understand the why and how of the phenomena in an in-depth manner.

\section{Conclusion}

Today's generations of pre-service ESL teachers are receptive in embracing and to seamlessly integrate technology in their classrooms which is crucial in meeting the needs of the 21 st century learning. There was a time where books and pens were considered useful tools in learning but in today's digital age, computers and its technologies are now changing our educational landscape (Bax, 2003) [32]. Therefore, it is imperative that pre- service teachers are guided to utilise ICT tools and integrate them in their lessons meaningfully.

\section{Acknowledgement}

The authors wish to thank the Faculty of Educational Studies, Universiti Putra Malaysia for their support provided throughout the process of this research.

\section{Corresponding author}

Nooreen Noordin, Faculty of Educational Studies, Universiti Putra Malaysia, 43400 UPM Serdang, Selangor, Malaysia.

Email: nooreen@upm.edu.my

\section{References}

Al-Mahrooqi, R. \& Troudi, S. (2014). Using technology in foreign language teaching. Cambridge Scholars Publishing.

Angeli, C. \& Valanides, N. (2008). TPCK in preservice teacher education: Preparing primary education students to teach with technology. Paper presented at the AERA Annual Conference, New York.

Cakir, H. (2013). Use of blogs in pre-service teacher education to improve student engagement. Computers \& Education, 68, 244-252.

Cohen, J. W. (1988). Statistical power analysis for the behavioural sciences (2nd ed.). Hillsdale, NJ: Lawrence Erlbaum Associates.

Dörnyei, Z. (2005). The psychology of the language learner: Individual differences in second language acquisition. Mahwah, NJ: Lawrence Erlbaum Associates.

Guadagno, R. E., Okdie, B. M., \& Eno, C. A. (2008). Who blogs? Personality predictors of b logging. Computers In Human Behavior, 24(5), 1993-2004.

Gülbahar, Y. (2007). Technology planning: A roadmap to successful technology integration in school. Computers \& Education, 49(4), 943-956.

Hamburger, Y. \& Vinitzky, G. (2010). Social network use and personality. Computers in human behavior, 26(6), 1289-1295.

Kim, H. K. (2008). Beyond motivation: ESL/ EFL teachers' perceptions of the role of computers. Calico Journal, 25(2), 241-259.

Landers, R. N. \& Lounsbury, J. W. (2006). An investigation of Big Five and narrow personality traits in relation to Internet usage. Computers in Human Behavior, 22(2), 283-293. 
INTERNATIONAL JOURNAL OF ACADEMIC RESEARCH IN BUSINESS AND SOCIAL SCIENCES

Vol. 9, No. 1, Jan, 2019, E-ISSN: 2222-6990 @ 2019 HRMARS

Lee, K. W., Thang, S. M., Tan, C. K., Ng, S. I., Yoon, S. J., Chua, Y. W., \& Nadin, S. S. (2014). Investigating the ICT needs of 'Digital Natives' in the learning of English in a public university in East Malaysia. Procedia-Social and Behavioral Sciences, 118, 242-250.

Lee, S. Y. (2013). Digitalizing the Malaysian Classroom: Barriers, Insights and Feasibility. Malaysian J. Media Studies, 15(1), 75-90.

Li, L. \& Walsh, S. (2010). Technology uptake in Chinese EFL classes. Language Teaching Research, 15(1), 99-125.

Mark, G. \& Ganzach, Y. (2014). Personality and Internet usage: A large scale representative study of young adults. Computers in Human Behavior, 36, 274-281.

McElroy, J. C., Hendrickson, A. R., Townsend, A. M., \& DeMarie, S. M. (2007). Dispositional factors in internet use: personality versus cognitive style. MIS quarterly, 809-820.

Moore, K. \& McElroy, J. C. (2012). The influence of personality on Facebook usage, wall postings, and regret. Computers in Human Behavior, 28(1), 267-274.

Norsiah, A. H., Mohd Sobhi, I. \& Siti, S. N. (2015). Facebook, YouTube and Instagram: Exploring Their Effects on Undergraduate Students' Personality Traits. The Journal of Social Media in Society, $4(2), 138-165$.

Atikah, N. A., Jafre, M. Z. A., Wong, S. L., Majid, O. \& Hanafi, A. (2006). The attitude and motivation of English language teachers towards the use of computers. Malaysian Online Journal of Instructional Technology, 3(1), 57-67.

Pallant, J. (2011). SPSS survival manual (4th ed.). New South Wales: Allen \& Unwin.

Pervin, L. A. \& John, O. P. (2001). Personality: Theory and research (8th ed.). NY: John Wiley \& Sons.

Pinner, R. S. (2012). Teachers' attitudes to and motivations for using CALL in and around the language classroom. Procedia-Social and Behavioral Sciences, 34, 188-192.

Prensky, M. (2001). Digital natives, digital immigrants part 1. On the horizon, 9(5), 1-6.

Rosnaini, M. \& Mohd Arif, I. (2010). Impact of training and experience using ICT on in- service teachers' basic ICT in literacy. Malaysian Journal of Educational Technology, 10(2), 5-10.

Ryan, T. \& Xenos, S. (2011). Who uses Facebook? An investigation into the relationship between the Big Five, shyness, narcissism, loneliness, and Facebook usage. Computers in Human Behavior, 27(5), 1658-1664.

Sang, G., Valcke, M., van Braak, J., Tondeur, J., \& Zhu, C. (2011). Predicting ICT integration into classroom teaching in Chinese primary schools: exploring the complex interplay of teacher-related variables. Journal of Computer Assisted Learning, 27(2), 160-172.

Shen, J., Brdiczka, O., \& Liu, J. (2014). A study of Facebook behavior: What does it tell about your Neuroticism and Extraversion? Computers in Human Behavior, 45, 32-38.

Smeets, E. (2005). Does ICT contribute to powerful learning environments in primary education? Computers and Education, 44, 343-355.

Wehrli, S. (2008). Personality on social network sites: An application of the five factor model. Zurich: ETH Sociology (Working Paper No. 7).

Yunus, M. (2007). Factors affecting the use of information communication technologies in teaching English as a second language in Malaysia. Doctoral dissertation, University of Bristol. 
INTERNATIONAL JOURNAL OF ACADEMIC RESEARCH IN BUSINESS AND SOCIAL SCIENCES Vol. 9, No. 1, Jan, 2019, E-ISSN: 2222-6990 @ 2019 HRMARS

Perkmen, S., \& Cevik, B. (2010) . Relationship between pre-service music teachers' personality and motivation for computer- assisted instruction. Music Education Research, 12(4), 415-425.

Bax, S. (2003). CALL-past, present and future. System, 31(1), 13-28.

Ministry of Education. (2012). Malaysian Education Blueprint 2013-2025. Ministry of Education Malaysia. 